\title{
The Two-Edged Sea
}

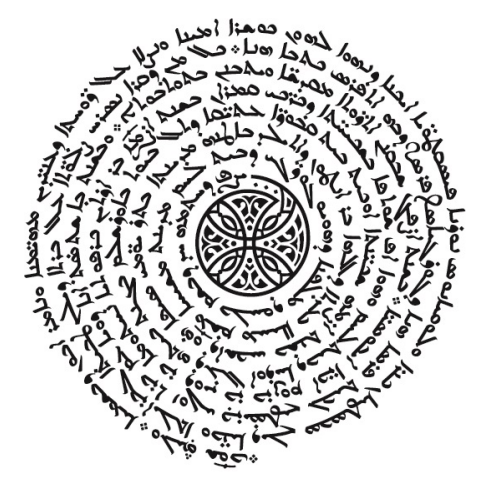




\title{
The Modern Muslim World
}

12

\author{
Series Editorial Board \\ Marcia Hermansen \\ Martin Nguyen \\ Hina Azam \\ Joas Wagemakers \\ Ussama Makdisi
}

\section{Advisory Editorial Board}

$\begin{aligned} \text { Talal Asad } & \text { Tijana Krstic } \\ \text { Khaled Abou El Fadl } & \text { Ebrahim Moosa } \\ \text { Amira Bennison } & \text { Adam Sabra } \\ \text { Islam Dayeh } & \text { Armando Salvatore } \\ \text { Marwa Elshakry } & \text { Adam Talib } \\ \text { Rana Hisham Issa } & \end{aligned}$

This series will provide a platform for scholarly research on Islamic and Muslim thought, emerging from any geographical area and dated to any period from the 17 th century until the present day. 


\section{The Two-Edged Sea}

Heterotopias of Contemporary Mediterranean

Migrant Literature

Nahrain Al-Mousawi

Gorgias

2021 
Gorgias Press LLC, 954 River Road, Piscataway, NJ, 08854, USA

www.gorgiaspress.com

Copyright (C) 2021 by Gorgias Press LLC

All rights reserved under International and Pan-American Copyright Conventions. No part of this publication may be reproduced, stored in a retrieval system or transmitted in any form or by any means, electronic, mechanical, photocopying, recording, scanning or otherwise without the prior written permission of Gorgias Press LLC.

2021

$$
1
$$

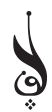

ISBN 978-1-4632-4372-2

ISSN 2690-2249

\section{Library of Congress Cataloging-in-Publication Data}

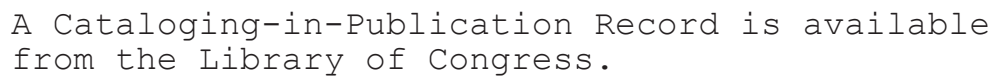

Printed in the United States of America 